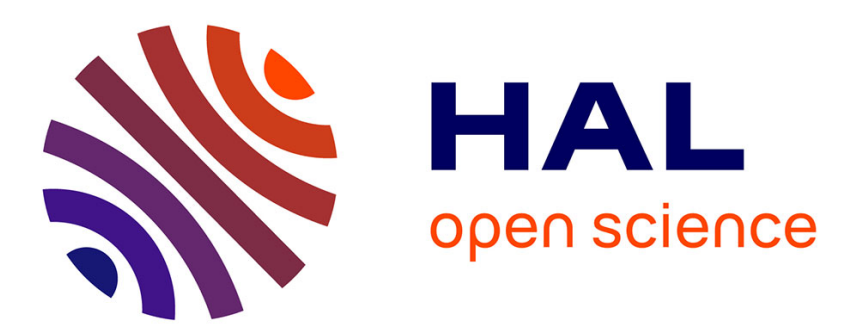

\title{
Alevist Movements at Home and Abroad: Mobilization Spaces and Disjunction
}

\author{
Elise Massicard
}

\section{To cite this version:}

Elise Massicard. Alevist Movements at Home and Abroad: Mobilization Spaces and Disjunction. new perspectives on Turkey, 2003, 28-29 (Spring-Fall), pp.163-187. halshs-00655802

\section{HAL Id: halshs-00655802 \\ https://shs.hal.science/halshs-00655802}

Submitted on 2 Jan 2012

HAL is a multi-disciplinary open access archive for the deposit and dissemination of scientific research documents, whether they are published or not. The documents may come from teaching and research institutions in France or abroad, or from public or private research centers.
L'archive ouverte pluridisciplinaire HAL, est destinée au dépôt et à la diffusion de documents scientifiques de niveau recherche, publiés ou non, émanant des établissements d'enseignement et de recherche français ou étrangers, des laboratoires publics ou privés. 


\title{
Alevist movements at home and abroad: Mobilization spaces and disjunction
}

\author{
Elise Massicard*
}

\section{Introduction}

The Alevist ${ }^{\dagger}$ movement developed almost simultaneously in Turkey and among Turkish migrants, but it is structured and acts quite differently in these distinct, albeit related, political spaces. This comparative empirical study tries to explain the differences in the discourses and the success of Alevist movements in Turkey and Germany by relating them to the broader institutional and discursive contexts within which they are embedded. Alevist movements are incorporated differently in state policies directed to claim-makers and consequently possess different discursive and institutional resources. Spatially bounded institutional contexts and political agendas frame the discourse and strategies of Alevist claim-making, and result in divergent developments. It is thus necessary to disentangle the multiple levels of claim- and policy-making involved (local, national and supranational), and to analyze their relationships and possible articulations. 'Transnational' mobilization has often been understood as a mere continuation of mobilization at home or, oppositely, as its driving force. This paper questions the continuity between mobilizations at home and abroad, and argues that mobilization in migration entails specific dynamics, which may not be re-imported home.

\section{Mobilizations, environments and frames}

\footnotetext{
Alevist identity politics

The Alevist movement can be considered as an affirmative 'politics of recognition', voicing demands in order to be recognized as a specific group and to obtain equal

* Centre National de la Recherche Scientifique / Centre d'Etudes et de Recherches administratives, politiques et sociales, Lille, France

${ }^{1}$ I have chosen to distinguish Aleviness, which covers the social fact, from Alevism, which designs the movement in the name of Aleviness.
} 
participation in all spheres of life without facing discrimination (especially with regard to the Sunnis). In the course of this movement's development, different groups - to some extent identifiable with organizations - have emerged with diverse, or even opposite representations of Aleviness. Some claim Aleviness is a purely religious matter - the 'real religion' of Turks or even Kurds. For others, it is a political philosophy of liberation, resistance and democracy. For yet another group, Aleviness is mainly a culture, a way of life characterized by criticalmindedness. Each group bases its representation on a reconstruction of Alevi history. Of course, depending on the political agenda, these stories vary: for example, those considering Aleviness as a revolutionary movement emphasize social uprisings - stylized as 'Alevi rebellions' - against the Selcuk and Ottoman dynasties. It is not our aim to describe here this diversity of positions, which has been discussed solidly in various works (Väth 1993, p. 216217 ; Vorhoff 1995). Suffice it to say that the lack of consensus on the nature, scope and contents of Aleviness, and even the level on which such an identity should be defined (religious, social, political, or cultural?) is a striking feature of contemporary Alevism. The numerous debates, accusations and criticisms on this topic, which constitute the main activity of Alevists, show that there is a constant struggle over its meaning.

For those Alevis who speak about Aleviness, the aim is to show that they are the right kind of Alevis, while 'the others' are wrong Alevis. These different groups try to establish a monopoly over the right definition and over the right to represent Aleviness, giving the Alevist movement its highly competitive character. It is not just about politics of recognition; it is also, and maybe above all, about politics of recognition as a particular kind of Aleviness. Even after fifteen years of mobilization, this debate over the definition of Alevi identity and its boundaries is not settled. Depending on the political situation and events, various interpretations become more or less influential. For example, after the Sivas slaughter in 1993, the religious representations of Aleviness were undermined, whereas more political and oppositional representations gained momentum. This changed after the Gazi riots in 1995, when opposition became less legitimate. But, until now, no group has managed to gain control over the definition of Aleviness.

Social movement scholars conceptualize this signifying work or meaning construction by employing the term 'framing'. The concept of frame, when used in the study of social movements, is derived from the work of Goffman, for whom frames denote 'schemata of

2 In this perspective, one should not underestimate the productivity and functionality of discursive ambiguity in such contested matters (Massicard 2003). 
interpretation' that enable individuals 'to locate, perceive, identify, and label' occurrences and events $(1974$, p. 21). At a social movement level, what mobilization theories call 'collective action frames' also perform this interpretive function by simplifying and condensing reality-but in ways that are action-oriented. Collective-action frames define some problematical situation as being in need of change, identify who or what is to blame, and suggest alternative sets of arrangements. For instance, for secular-minded Alevists, Alevis' problems stem from Islamists having taken power, destroyed Turkey's secular heritage and introduced discrimination against Alevis; thus, secularism and the impartiality of the State should be restored. But for some more religious-minded Alevists, the problem is elsewhere: the secular State has an oppressive dimension regarding religion, and this is what should be changed in a liberal manner, so that Alevis, as well as other Muslims, can practice their religion freely. Thus, Alevist groups differ first of all in terms of issues they address and the corresponding direction of attribution. Depending on their interpretation of Aleviness, Alevists do not adopt the same discourse, and nor do they problematize the same institutions. For example, those who claim Aleviness is a religion and should be recognized as such, like the CEM foundation, demand the inclusion of Aleviness in those state institutions dealing with religion, while for others, like the Pir Sultan Abdal association, these institutions should simply be abolished. Therefore, collective action frames are sets of beliefs and meanings that inspire and legitimate the activities and claims of social movement organizations.

Since they are the outcome of negotiating meanings, collective action frames are not static, reified entities, but are continuously being constituted, contested, reproduced, transformed, and replaced in the course of social movement activity ${ }^{\mathrm{ii}}$. Thus, framing denotes a processual and interactive phenomenon (Benford and Snow, 2000, p. 614). Consequently, these groups are not static communities with clearly defined boundaries, but rather dynamic political locations where certain views and sometimes organizations ally (Erman and Göker, 2000, p. 105). Whereas this debate is often understood as concerning Alevis alone, it has a broader scope. Not only activists and Alevi masses, but also the media, different political groups, and institutions take an active part in these 'framing contests' (Ryan 1991), with an attempt to 'rebut, undermine, or neutralize a group's myths, versions of reality, or interpretive framework' (Benford 1987, p. 75). The numerous articles printed in dailies and national TV programs on this topic attest to the public character of this debate, at least in Turkey.

Among external actors involved in what has been referred to as 'the politics of signification' (Hall 1982), one should mention political actors like Turkish and Kurdish 
nationalists, Islamists, and secularists, who produce and spread influential views on Aleviness, and sometimes - most of the time implicitly - ally with some Alevists against others. Another major role is played by institutions, which sometimes bring about specific views on Aleviness, but above all also provide opportunities. Institutions manage important political and economic resources, distribute (or withhold) subsidies to organizations to encourage them, award (or deny) state aid to groups so as to organize activities. In the end, institutions define legitimate categories to be claimed, and criteria to be fulfilled. Thus, there are constant interactions between institutions and claim-makers. The state is an active partner in granting allocations and recognition, but also - even if indirectly - in claim-making and therefore in framing processes.

On the whole, claim-makers do not bring about claims isolated from the surrounding institutional framework and political actors. Social movement framing processes and activities do not occur in a political or institutional vacuum, but within an institutionally structured space. Claims and debates over identity and recognition are very much shaped by elements from the socio-political context in which they are embedded, including the framings of institutions and other actors. In order to study a movement's activity, it is therefore crucial to take into account interactions between organizations and their environment.

\section{Alevist movements and their environments}

Drawing on the social movements literature, we can refer to these institutional frameworks as 'political opportunity structures', which 'consist of specific configurations of resources, institutional arrangements and historical precedents of social mobilization' (Kitschelt 1986, p. 58) and thus shape the levels and patterns of mobilization by providing certain resources, constraints and models for organizing. Since this concept may be considered as imprecise, one may distinguish the level of political superstructure which defines a stable, binding frame for all political actors (like the nature of the regime, the unitary or centralist nature of the State, the existence of statuses to be claimed, etc.) from the more easily changing, contextual level of power balances (Gamson and Meyer 1996). Political opportunity structures are generally considered as being national but, as we will see, can also be regional or local. Moreover, they are not identical for all movements in one political space. Concerning one given movement, the political opportunity structure defines the availability and relative attractiveness of different options for collective action that challenger groups face and perceive. It denotes variables like the status of the group in its 
environment, and perceived political constraints affecting claim-makers and institutions. What is interesting to us here is how political opportunity structures and their perception affect Alevists' activities and framing processes.

Movements, like Alevism, being active in different political spaces are confronted with different political opportunity structures. The crucial role played by the institutional and political framework in the country of settlement on the migrants' patterns of organization and on their claim-making process has been analyzed (Koopmans and Statham 2000). In this respect, the most common approach is to compare one migrant group in several receiving countries, probably because it points to the ever popular issues of policies of reception and integration. But political opportunity structures of the receiving countries are rarely compared to those of the country of origin, probably because to compare political opportunities and their perception as native citizens and as migrants may not allow any systematic comparison. However, since our aim here is not comparison as such, but to describe the disjunction between movements in different political spaces, we will compare political opportunity structures, as they are faced and perceived by the Alevist movement, at home and in Germany. Aleviness being a specifically contested and fluid topic, with no prevailing organization or interpretation, its framings may vary greatly depending on the institutional and political framework in which it is embedded. In fact, the groups and interpretations mentioned above are present in both countries, but in different proportions.

\section{Alevism in Turkey: an impossible recognition?}

The Turkish State is unitary: it denies any group specific features and criminalizes any particularism as 'separatism', even more so since the beginning of the Kurdish nationalist movement. There is no recognized status as minority ${ }^{\ddagger}$. Thus, the Turkish context provides very narrow opportunity for any kind of recognition of particularism.

In the religious field, Aleviness was stigmatized under the Ottomans and later officially denied in the Turkish Republic, although it was officially secular. Speaking about a separation of State and religion in contemporary Turkey would be misleading. Rather, one should speak about a domestication of religion by the State, which mainly manifests itself through the Directory of Religious Affairs (DİB). This institution has a monopoly over

\footnotetext{
${ }^{3}$ The list of recognized religious minorities, all of them non-Muslim, was fixed by the 1923 Lausanne Treaty.
} 
official religion, especially over the nomination and management of its clergymen. Far from being religiously neutral, the Turkish State has institutionalized the Sunni interpretation of Islam as the official denomination by default (Bozarslan 1994). Consequently, the DİB considers Alevis as being Muslims who have somehow been pushed out of the 'true path'. No different treatment is reserved or even allowed to them: Alevi children must attend compulsory religion courses at school, where exclusively Sunni interpretations are taught. Despite their claims and the debates they instigated, the Alevists have obtained neither any recognition of their religious status nor the introduction of Aleviness into the compulsory religious education. They have also failed to obtain the abolition of either the DİB or the compulsory religion classes - all of these being among their most important claims.

Consequently, while mosques and churches, recognized as worship places, are exempted from water and electricity charges, cemevi, the so-called Alevi worship places, are not.

In the cultural field, the situation is somewhat different. Some cultural elements which can be attributed to Alevis, like songs or poems, were integrated into the official culture and encouraged. However, they have often been cleaned of any Alevi component and thus 'neutralized' (Coşkun 1995, p. 208, 214). In this way, institutions like the Ministry of Culture have attempted to 'rehabilitate' Aleviness within the framework of Turkish national culture, whilst denying it any specific character outside this framework.

Regarding political balances, it is important to make clear that Alevist demands were not supported nor relayed by any political party, not even by those that Alevis most supported (Schüler 1998, p. 242-245 for social-democratic parties ; Massicard 2002, p. 468-472 for other parties). Up to now, claims for recognition or specific treatment remain illegitimate, and no party would take the risk of being identified as an 'Alevi party', and thereby risk losing votes of non-Alevis.

On the whole, the Alevist movement has failed to obtain any kind of recognition or of specific treatment by the Turkish State. Some minor subsidies have been distributed to mostly State-friendly Alevist organizations for cultural or social activities - especially at a local level, or in times of general mobilization against Islamists. State institutions do not any longer deny the existence of Aleviness; they mostly defend an Aleviness molded in Turkish nationalism, but not Alevism. Therefore, they don't really favor one particular organization, and do not encourage any of the competitive tendencies within the Alevist movement. By hindering the formation of a unique official Alevi interlocutor, they have indirectly contributed to the split 
of the movement. One may assume that they even took advantage of its divided character and consequent weakness to ignore its claims.

\section{Alevism in Germany: from Culture to Religion?}

In Germany, political opportunities for Alevis are, of course, different. There, the Alevi issue is derivative from the 'migration' issue. As migrants, they have fewer rights and political opportunities than native citizens (for the political opportunities of migrants in Germany, see Amiraux 2001). Options for claim-making and recognition nonetheless differ, and have widened in recent years.

In the religious field, Germany is not a secular State: State and religion are not separated, but cooperate. This is mostly the case for educational matters. In principle, religion is taught in public schools. Religious institutions determine the content of religion courses, while the State is responsible for the organizing and financing of these courses, assuring their conformity with constitutional principles. On this basis, the claim from religions for institutionalization refers to specific legal status. The highest legal status for religious groups is public law corporation (Körperschaft des öffentlichen Rechts). The required conditions to be granted this status are quite severe: stability, sustainability, a clear organizational structure, and a certain number of members. Otherwise, the status of religious community ${ }^{\S}$ is more advantageous than being a mere association: a religious community cannot be disbanded easily, and may provide religious teaching in public schools. Thus, the main goal for the mobilization of religious groups - be they migrants, like Muslims, or not, like Jehovah's witnesses - is to obtain a legal status.

However, this opportunity was passed up by Alevists until recently, since it was not perceived as such. As migrants, Alevis did not initially claim any distinctiveness, since they thought they were there temporarily. This changed in the course of the 1970s. In the 1980s and 1990s, as mobilization was beginning and as multiculturalism gained momentum, the issue of immigration to Germany was treated mainly in terms of cultural difference. Multicultural policies provided many institutional opportunities, resources and space for the institutionalization of 'cultural' organizations (Vertovec 1996). Thus, they shaped the institutional and discursive framing of migrants' claim-making. After Turks and Kurds, the heightened awareness of questions concerning cultural identity was also applied to Alevis.

\footnotetext{
${ }^{4}$ Articles 7/3 and 140 of the German Basic Law (Grundgesetz).
} 
Aware of the political support for multiculturalism, Alevists negotiated with the German society for subsidies or integration, and began to stress their distinctiveness and to frame it mainly in terms of a culture in need of protection (Kaya 1998).

We can assume that the existence and perception of this cultural opportunity helped to structure the Alevist movement and contributed to the emergence of a central organization, the Federation of Alevi Communities of Germany (AABF). The AABF, although claiming until recently a mainly cultural version of Aleviness, manages to incorporate different views. The Alevist movement is less divided in Germany than it is in Turkey because the German environment is less polarizing for Alevists than the Turkish one. Among the major Turkish migrants' organizations in Germany, the AABF is the only one that is not a direct progeny of any 'mother' organization in Turkey.

\section{The opening of a religious opportunity: the Berlin case}

The issue of plurality in German public space is posed most acutely by the large number of Turkish migrants. Still, the religious identity of the mainly Muslim immigrants had nearly no impact on integration policy until the mid-1990s when, in accordance with the 'global' agenda, attention was drawn to 'fundamentalist' sympathies among the Muslim youth, and the religious dimension of immigration came to the fore (Heitmeyer 1997). Until then, recognition had not been obtained by any recent migrant religion, a failure related to the difficult acceptance by the German society of non-Christian migrants. Therefore, Alevis did not perceive the potential of obtaining religious status as an opportunity ${ }^{* *}$.

\section{The legal incorporation of religious difference in Berlin}

In February 2000, a high administrative court recognized an Islamic organization, the Islamic Federation of Berlin (IFB) as being a religious community, granting it the right to provide religious education in public schools. This recognition was obtained at the specific institutional level of the Länder. In Germany, federate States are responsible for worship and educational matters. For this reason, the recognition of religious groups, and the organization of their ability to teach in public schools, is a Land matter. Groups being granted these statuses differ from one state to the other, even if some of them are recognized everywhere.

\footnotetext{
${ }^{5}$ The AABF demanded recognition as a civil law corporation in 1995. However, this initiative was not really followed by mobilization, since it was considered as somehow 'hopeless'.
} 
At the same time, each State offers different legal opportunities to religious education (Özdil 1999).

A few weeks after this recognition, the Anatolian Alevis' Cultural Center (AAKM), Berlin's most important Alevist organization (affiliated to the AABF), suddenly interested in this possibility, asked for the same status as the IFB. The recognition of the IFB does not imply its monopoly over the representation of Islam. This can best be explained by the German tradition of bi-denominationalism: in principle, the German State has to be religiously neutral towards all different religions and denominations, and must guarantee the equality of all religious persuasions ${ }^{\dagger \dagger}$. This principle originates from the parity recognized between the two Christian communities. Unlike the Turkish State, German institutions do not have difficulty understanding the duality between Sunnis and Alevis. Alevists sometimes take advantage of this by presenting themselves as 'the Protestants of Islam' ${ }^{\prime+}$. This explains why the recognition of one Muslim religious community does not imply its exclusive representativeness of Islam, but on the contrary opens the way to demands by other Muslim groups. Noticing the opening of religious opportunity, activists began to frame Aleviness as a religion in need of protection and equal rights with Sunni Islam, the framing of equality of rights being very legitimate in Germany. And as early as 2000, the AAKM was given the status of a religious community.

\section{The local political balance}

It should be noted here that the AAKM obtained the status of religious community much more quickly and easily than the IFB did. While the IFB was involved in a twenty-year legal battle (the first request from the IFB was sent in 1980), the AAKM obtained the status only a few months after having applied. This appears a bit strange, first of all because of the numerical size of the two 'communities': Alevis in Berlin are far fewer than Sunni Muslims, and members of the AAKM much less numerous than members of the IFB. Moreover, the IFB was much more active on the issue and called for a far more massive mobilization than the AAKM did. How can the differential treatment of the IFB's and AAKM's requests by the Berlin local authorities be explained?

\footnotetext{
${ }^{6}$ Article 4 of the Basic Law.

${ }^{7}$ Interview with an activist of the AAKM, Berlin, $4^{\text {th }}$ August 2001.
} 
The first hypothesis is that the AAKM fulfils the requested legal conditions to obtain the status of religious community better. But this hypothesis can hardly be defended. In fact, the reasons put forward during twenty years to refuse the status to the IFB (Oberverwaltungsgericht Berlin 1998) could have easily been put forward to reject the AAKM. The first reason put forward was the lack of a unique interlocutor representing all Muslims and of a single indisputable and shared Weltanschauung (world view). But among Berlin Alevis also, different orientations and theological views coexist. The AAKM is the dominant Alevi organization, but it was and is still contested by other organizations, with which it did not reach an agreement to make a joint request for recognition. Even among the AAKM's members, the existence of a shared Weltanschauung is highly questionable. The second reason that had been advanced was that the internal organization of Muslim worship is not based on any church-like hierarchy. But among Alevis, there is no church-like hierarchy, and the role of the dede, the traditional religious authorities, is unclear and contested, because of both the lack of a general hierarchy among them, and due to the breakdown of traditional religious institutions and the transmission of dede status (Sökefeld 2002).

Legally speaking, there was no reason to recognize the AAKM a religious community while the IFB had been rejected, or to do it more quickly. The only possible legal reason is the fact that the decision to recognize the IFB, and thus to give Muslim children the same right to receive religious education as Christian children, constituted a precedent to the recognition of the AAKM. But a mere precedent does not constitute grounds for decision. The last judicial criterion is 'conformity of the religious community to the basic law' (i.e. the constitution), which was always suspected not to be the case for 'mainstream Muslims'. However, this is more a political argument than a purely judicial one.

It seems in fact that the explanation of this differential treatment may well be a political one. Islam in Germany, like in most West European countries, enjoys a very negative image. It is often assimilated with 'reluctance to assimilate', with backwardness, with 'issues' like 'the veil', or directly with 'fundamentalism'. The recognition of the IFB, criticized for its supposed relations with Islamist parties in Turkey, was very controversial. In this perspective, the recognition of an Alevi association provided a counterweight to a religion, and to an organization, that were negatively perceived. Indeed, the manner in which the AAKB presents itself to the German public is highly significant: it stresses the Alevis' difference from the majority of migrants from Turkey - which Alevists systematically do - and implicitly puts a distance between itself and a stigmatized Islam. Many Alevis actually share these negative 
views on Sunni Islam and even contribute to spread the stereotype that it is a 'fundamentalist danger'. They present themselves, in contrast, as bearers of a more democratic, more tolerant, and more 'modern' Islam ${ }^{\S}$. For example, they often insist on the equality of sexes which they claim to practice, implicitly or explicitly suggesting that 'bad' Sunni Muslims practice sexual discrimination and are thus neither integrated nor modern ${ }^{* * *}$. In the same way, Alevists in Germany insist on the conformity of their cult to the German Basic Law, which is always a point of suspicion concerning 'mainstream' Muslims.

This representation has been widely adopted by the German politicians who are aware of the differences between Sunnis and Alevis. They are quick to use the Alevis as an example of Turks who 'successfully integrate' (Mandel 1990, p. 156). During an Alevi 'cultural night' organized by the AAKM in 1996, Hans Nisblé (the social-democrat mayor of the district of Wedding), attempted to position Aleviness as a political counterweight against Islamic radicalism. He even called upon the German people to stand by the Alevis against the challenge of 'radical Islam from within' prevailing over Europe and Germany (Kaya 1998, pp. 42-43). This representation is also found in the press. The quotidian Die Tageszeitung speaks about 'liberal Alevis' in opposition to the IFB, and defines them as 'non-dogmatic Muslims ${ }^{\text {iti† }}$. So Aleviness is exempt from the alarmist representations widespread about mainstream Islam. Alevis are remarkably absent from the official reports on the protection of the Constitution (Verfassungsschutzberichte), something which is far from being the case for Turkish Islamists. The favorable perception of Aleviness by the German media is directly related to the Western reading of contemporary Turkey, which sees the secularist and 'modern' regime being threatened by radical Islam (Kaya 1998, p. 43).

Beyond a 'juridical' appearance, with clear-cut criteria defining a status, the differentiated treatment of denominations seems to be clearly related to the political stakes concerning the presence of Islam in Germany. The granting of an institutional status implies an implicit hierarchization of groups by official institutions.

\section{Toward a 'denominationalization' of Aleviness in Germany?}

In this particular case, the judicial arm of the German state has recognized religious currents as putatively bounded groups. The relational differences between religious currents

\footnotetext{
${ }^{8}$ See for example press conference, AAKM, Berlin, $5^{\text {th }}$ November 1999.

${ }^{9}$ See speeches during the celebration of women's day at the AAKM, Berlin, $8^{\text {th }}$ March 2001.

${ }^{10}$ Die Tageszeitung, $19^{\text {th }}$ April 2000.
} 
are hereby stylized into differences between objectified categorical identities and quasicorporate 'communities'. This recognition of 'communities' encourages the latent tendency to stereotype their commonalities, essentializes their seemingly homogeneous culture, and ascribes to them a unified collective will. The communities established through incorporation are co-opted into processes of political consultation, as well as integrated into the flow of state-controlled resources (see Baumann 1998). Moreover, this transformation of a religious current into a religious community by state institutions induces a self-transformation by Alevists themselves into a kind of 'denomination' on the Christian model.

What should be noted here is that before the recognition of the IFB, the AAKM claimed Aleviness should be taught, but in a non-denominational manner: it demanded the inclusion of Aleviness in a course that would be non-denominational, general religious education (religiöse Unterweisung), since 'only this system would encourage tolerance and mutual comprehension't+. The position of the AABF was the same (AABF 2002, 9). But as soon as the right to teach was given to a Sunni organization--albeit partial and contested--, the AAKM applied for the establishment of a separate, competitive, denominational course as well. If Islamic instruction is introduced, they argue, the interest of Alevis too must be taken in account. Thus, they moved from a generalist and 'supra-denominational' stance to a particularistic and denominational one.

The recognition of the AAKM also leads indirectly to the transformation of Aleviness in Berlin into a denomination, or a kind of 'Church'. One sign of this tendency is the process of renaming the AABF. Instead of 'Federation' - a term remaining from the time of big political organizations and trade-unions at the national level - the AABF considers the possibility to adopt the term 'Community of Alevis in Germany' (Gemeinde der Aleviten in Deutschland), the term Gemeinde being much more associated with religion. In order to be recognized as a religious community in other Länder, and as a civil law corporation, the $\mathrm{AABF}$ also has to prove the existence of a clearly identifiable organizational structure; thus, it initiated a modification of its statutes and its internal organization. In order to obtain this status, the AABF has to furnish proof of a binding religious authority. Therefore, it is in the course of redefining the role of the dede $e^{\S \S}$.

\footnotetext{
${ }^{11}$ Interview with the director of the AAKM and a board member of the AABF, Berlin, Berlin, $16^{\text {th }}$ January 2001.

${ }^{12}$ Interview with a board member of the AABF, Berlin, $16^{\text {th }}$ December 2001.
} 
It also has to furnish proof of a consensus on dogma and belief, a quite difficult task concerning Alevis. In the past, the teachings were handed down orally within different holy lineages and in special ceremonies. Due to the often divergent oral traditions held by the holy lineages, it would be exaggerated to speak of a single and coherent Alevi system of beliefs. Yet, this is exactly what is required today. Thus, the AABF founded in 1999 a 'Commission for Religious Instruction', which pursues the aim of developing a 'teachable' religion so as to meet the legal requirements. In order to succeed in the negotiations over religious instruction, this commission initiated the writing of a syllabus (AABF 2002). The production of a basic textbook breaks new ground, since it represents the first organized effort to write down, systematize and unify the dogma and beliefs and institutionalize learning in Aleviness ${ }^{* * * *}$. In the syllabus, specific features differentiating Aleviness from orthodox Islam are stressed, and Aleviness is presented as a coherent system of belief on the model of Christianity. For example, although traditionally there weren't really any Alevi specialized religious buildings in which cem, the main religious ceremony, was celebrated ${ }^{\dagger \dagger \dagger \dagger}$, the syllabus presents cemevi (cem house) as 'the' worship place of Alevis, like the church or the mosque (AABF 2002, p. $32-33)^{+1+t}$.

Therefore, legal recognition has sociological consequences on the internal organization and political balances of Alevist organizations in Germany. As the requirements for recognition are basically derived from Christian traditions in Germany, adjustment to them will undoubtedly cause further transformations. Should we, thus, speak about a sociological transformation of Aleviness in Germany towards a denomination? In the public sphere, there is a general tendency towards the reconstruction of Aleviness as an Islamic denomination. However, since these external discourses concern mainly activists and organizations' leaders, they must not directly influence the representations of members or of Alevis, for which this whole debate may well be of little significance. It is still too early to evaluate the results of the teachings of Aleviness in public schools - which began in Fall 2002 in a very limited scope and of the internal reorganization of the associations. In the meantime, one may assume that this shift of 'Alevism' will not directly lead to a transformation of 'Aleviness'.

\footnotetext{
${ }^{13}$ There have been other attempts, mostly in Turkey. These, however, were not successful, due to the numerous divergences and the lack of opportunity to institutionalize this effort.

${ }^{14}$ In ordinary villages, the ceremony simply takes place in a large room of a family house. Specialized religious buildings exist only in centers of pilgrimage and, since the 1990s, in Alevist organizations. Recently, some are also being constructed in Alevi villages.

${ }^{15}$ Meeting the religious requirements was in fact quite difficult, since the syllabus has been set back many times by the authorities because of its lack of a professional character.
} 
Anyhow, these developments are quite remarkable because, as has been argued above, Alevists in Germany had until then expressed their specificity mostly in political or in cultural terms. In Germany, there is a stronger tendency than in Turkey to situate and reconstruct Aleviness outside Islam and to underestimate its religious dimension. Most Alevi organizations in Germany, including the majority of those affiliated with the AABF, had a generally secular attitude and remained largely indifferent towards religious questions. The predominant view was that Aleviness is a culture based on democracy and humanism. In fact, the great majority of Alevi associations in Germany carry in their name the word 'culture' (Sökefeld 2000, pp. 5-6) which is understood as being in opposition to religion, itself associated with backwardness. Since their creation, only a few Alevist organizations in Germany have shown a clear religious orientation, and most of them are not affiliated with the AABF. Unlike in Turkey, where some associations organize weekly cem, Aleviness was hardly reconstructed as a religion in Germany until now. Today, however, more and more organizations, first of all those affiliated with the AABF, stress a religious dimension, adopt more religious names, and consider themselves as worship places. As a consequence, two cemevi have recently been built in Germany.

Could these recent developments towards a religious conception of Aleviness be a consequence of sociological developments? The fact that the first migrant generation is now retired and may feel more religious needs may well be a factor. Did the pensioners marginalize the most influential generation in the organizations, that of Alevist leaders who are mainly - more often than in Turkey - secular, former leftists, often political refugees of the 1970s and 1980s? This is not likely. In fact, those who are leading this 'religious turn' are not the first generation of now elderly Gastarbeiter, but the former leftists, who have today tempered their former secularism, or even atheism.

On the whole, this increased emphasis on religion is not so much due to a regained strength of religiosity. It appears rather as a strategic response to changed public discourses and an adjustment to prevailing legal conditions, institutional opportunities and political discourse. This new framing seems to be strategic, deliberate, and goal oriented, since it is developed to achieve a specific purpose. Alevists make strategic efforts to link their interpretive frames with those of actual or prospective resource providers (Benford 2000, p. 624). A significant indication for this 'strategic' interpretation is that the organization being granted a religious status is not nearly the most religious one; rather it is the biggest and the most orientated towards German institutions and public sphere. Another argument supporting 
this interpretation is that Alevists in France - who are 'sociologically' similar to those in Germany, secular, mainly former left-wing militants - have not adopted this religious tone. France adheres strictly to the principle of laicité, which implies a clear-cut separation of religion and State, and severely limits the possibilities for the recognition of religious groups and identities. In France, a more 'secularist' and 'humanist' framing, stressing, for example, the high value given by the Alevis to human rights, yields results, and is politically and strategically more pertinent (FUAF 2000).

\section{Unification through recognition?}

Another crucial development is that this opportunity has led, to some extent, to the setting aside of internal debates on Aleviness. Most - even non religious-minded - Alevis seem to support the demand for religious instruction. While the view that religion should be kept out of school is met with great approval, it is stressed that if Sunnis are granted the right to religious instruction, the Alevis should strive for it as well. Therefore, the fact that Aleviness is recognized and taught seems to be more important than the way it is (KehlBodrogi 2001). Thus, the desire for recognition of Alevi identity and the equality of rights with regard to Sunni Islam appears more important than the way Aleviness is defined. For the $\mathrm{AABF}$, one of the main tasks of the syllabus is not only the transmission of knowledge on Alevi belief and culture (and of one interpretation of these), but 'identity building', i.e. the reinforcing of Alevi identity (AABF 2002, 10). The paradox is that the religious dimension may not be as important for Alevis as is the recognition of a status.

This is also the case on an organizational level. For the first time, the struggle for recognition has managed to bring together competing Alevist organizations in Germany despite their strong ideological, political and personal divergences. The AABF, the Federation of the Alevis of Kurdistan (FEK), close to the PKK, and the German branch of the Turkish CEM foundation, joined to support a separate course in Aleviness, and created a Committee of Education of Alevi Organizations ${ }^{\S \S \S}$ to represent the only binding authority on educational matters. This joint struggle even led to the setting aside of internal debates on Aleviness in order to reach an agreement on the outward representation of Aleviness as a branch of Islam, a difficult task considering the profound divergences. As a consequence, the opening of a religious opportunity led to a kind of strategic consensus among Alevists in Germany on the 
outward framing of Aleviness as a branch of Islam for purposes of recognition and resources, and to the undermining of internal debate and dissension.

\section{Local national and elsewhere: multiple policy levels and 'transnationality'}

A last question remains to be answered: the recognition of the AAKM as a religious community occurred at a local level, because of the exclusive competence of the federate states in educational issues. However, the religious shift of Aleviness concerns Germany as a whole. Why? Do these developments have consequences on the situation in Turkey, or are these political spaces relatively impervious to each other? Whereas some actors try to generalize, nationalize or even transnationalize these developments, others attempt to dissociate them. Here, we have to disentangle the multilevel institutional environment, as well as the different levels of claim- and of policy-making.

\section{Multiple levels of policy-making}

First of all, one should not overestimate the coherence of institutions in a given political space. The recognition of the IFB, and then of the AAKM, was undertaken by the judiciary, in accordance with the mainly juridical treatment of issues concerning migration and the religion of migrants in Germany (Amiraux 2001). However, other German institutions criticized this decision very strongly, in principle or because of the assumed relations of the IFB with Milli Görüş. The Berlin school administration feared that the introduction of a separate Islamic teaching would hinder tolerance among pupils from different religious backgrounds. Many German politicians from all parties criticized this very controversial decision, as did most German-Turkish politicians. Even many Turkish migrants' organizations in Berlin contested the decision, claiming they did not feel represented by the IFB. Thus, the organs of jurisdiction can be considered to be relatively independent from political instances, which mostly opposed this decision.

In the same way, the federate state employs processes of registration and functional devolution in order to carry out civic tasks, like religious teaching in public schools. In this perspective, the state of Berlin has a crucial place in Germany. Berlin was a pioneer for multicultural policies in the 1980s (Vertovec 1996). To achieve a 'cosmopolitan, tolerant and

${ }^{16}$ AKEK, Alevi Kuruluşları Eğitim Kurulu. See H. Özkan, "Alevi Inancı Eğitim Üst Kurulu", Özgür Politika, $18^{\text {th }}$ November 2000. 
liberal Berlin', in which permanent foreign residents are successfully integrated, constituted one of the main objectives of the 1991 policy guidelines of the Berlin government (Çağlar 1998, p. 251). As the capital of the new, unified Germany, Berlin has an even more symbolic role in the management of diversity. Given the difficult history of Germany regarding its immigrant populations, this task of making sure that 'Berlin offers images reflecting advanced modes of managing cultural diversity' (Vertovec 1996, p. 382) is critical for the local and national government. While the centralized legislative and executive organs of the German nation-state strive to maintain a 'neutral' civic equality, the organs of jurisdiction, and local government don't. The multiplicity and contradictions between different state institutions, as well as the relative autonomy of the judiciary and of the federate state, therefore offer opportunities for migrants' claims.

\section{'Nationalizing' recognition}

Profiting from these local dynamics, the AABF tried to generalize this recognition to a national German level. A few weeks after the recognition of the AAKM, the AABF started a campaign to apply for recognition as a religions community in all states where Alevis are settled. On behalf of affiliated organizations, the AABF made similar applications to four other states. Consequently, these four states, considering that this issue is not local, but national, decided to give a common answer to this request - something which has not yet been done. The interesting point here is that the issue of recognition, local at the beginning, is being nationalized both by activists and institutions.

\section{'Transnationalizing' recognition and the EU level}

A further policy- and claims-making level must been added to these local and national developments: the EU level, this time concerning Alevis in Turkey. In December 1999, at the Helsinki summit, Turkey was recognized as a candidate to the EU. The conditions Turkey must fulfill in order to begin negotiations for membership are the Copenhagen criteria, including the protection of minorities. In November 2000, the first Regular Report from the Commission on Turkey's Progress towards Accession stated that:

the official approach towards the Alevis seems to remain unchanged. Alevi complaints notably concern compulsory religious instruction in schools and school books, which would not reflect the Alevi identity, as well as the fact that financial support is only 
available for the building of Sunni mosques and religious foundations. These issues are highly sensitive; however, it should be possible to have an open debate on them. (European Commission 2000, p. 18).

This statement is reiterated almost in the same words in later reports. The interesting point is that it is situated in the section concerning freedom of religion, itself included in the chapter on 'civic and political rights', and not in the chapter on 'rights and protection of minorities', concerning mainly Gypsies and Kurds. Thus, the European Commission has implicitly recognized Aleviness as a religious phenomenon, and legitimized Alevis' demands. Thus, the Alevi issue has been inscribed in Turkey's European agenda among the points of necessary improvement for EU accession.

In 2000, Aleviness was both recognized as a religious community in Berlin and inscribed in Turkey's European agenda, albeit in a disconnected manner. Since then, Alevists in Germany and Turkey have attempted to take advantage of these developments to obtain recognition in Turkey itself, putting transnational linkages into practice ${ }^{* * * * *}$.

\section{The limits of transnationalization and the reactions 'at home'}

However, until now, these attempts have not been successful. Unlike in Germany, Alevists in Turkey did not clearly reframe Aleviness more religiously. Since religious recognition, as argued above, is probably the most difficult to achieve in Turkey, this has hindered the 'exporting' of recognition. As a matter of fact, the recognition of Aleviness in Berlin may well have hardened the attitude of the Turkish authorities and of many political actors against Alevism, making its claims even more illegitimate in their eyes.

Turkish media and authorities reacted quite negatively to the recognition of the AAKM as a religious community in Berlin ${ }^{\dagger+\dagger \dagger}$, as it is often considered as dangerous to the Turkish nation and its unity. The recognition of both the IFB and AAKM were strongly criticized, since it excluded the sending state from the managing of the very sensitive issue of religion in migration, an issue it had been trying to maintain control of, for example through the foreign branch of the DİB, the DİTIBB. Through this decision, the Turkish authorities are no longer the exclusive or privileged partners of German institutions in religious matters

\footnotetext{
17 "AABF başkanı Öker: Berlin örnek olacak", Milliyet, European edition, $7^{\text {th }}$ July 2000.

${ }^{18}$ See for example R. Aksu, "Berlin'de Alevilik Dersi", Milliyet, $7^{\text {th }}$ July 2000 , p. 22 ; "Almanya'da 'Alevilik Dersleri' oyunu", Hürriyet, $14^{\text {th }}$ February 2001.
} 
concerning Turkish migrants. Moreover, institutions felt threatened by the acquisition abroad of a right they had always refused to grant.

This negative reaction was accentuated by an incident in June 2000, itself related to the inclusion of the Alevi issue on Turkey's European agenda by the Commission. In the course of the preparation of the report, Alevist organizations presented their claims to European Union officials. They formulated their usual demands ${ }^{++1+}$, but for the first time on a European arena. The Turkish ministry of foreign affairs found itself in an awkward position, because it had not been informed about this meeting. Thereafter, most Turkish media denounced the EU for introducing itself into Turkey's internal matters, and the Alevists for negotiating with the EU against Turkey and its national interest ${ }^{\S \S \S \S}$. The Alevi issue being placed on Turkey's European agenda, without the Turkish government's awareness and approval, Turkish institutions were again bypassed.

A few months later, the most influential Turkish daily, Hürriyet, began a virulently nationalist press campaign against the $\mathrm{AABF}$, far beyond the normal coverage of Alevist activities in Europe (Sökefeld 2001) ${ }^{* * * * * *}$. Giving coverage to the general assembly of the federation, the daily accused the AABF of irregular financial practices, before criticizing its general political stand. Among others, it accused the AABF of being influenced by the German government or even of working for it, of alienating the 'Alevi community' from the Turkish nation, and of transforming it into a tool of German interests against Turkey; in short, it suspected the AABF of separatism, of defending the Armenian genocide thesis, and of supporting Kurdish 'separatism'. Further, AABF's request of the right to give courses of Aleviness in German was interpreted as an attempt to compete with the mother tongue religious courses given by Turkish consulates in Germany, and thus to 'acculturate' Alevis instead of defending the transmission of Turkish culture ${ }^{+\dagger \dagger \dagger \dagger \dagger}$. Hürriyet reminded the AABF that, as a Turkish organization in Germany, it was responsible for defending Turkey's national interests, for example, concerning its accession to the EU. Obviously, the aim of this campaign was to weaken the AABF, perceived by Hürriyet as being a danger to Turkish national interest. It is not the first time that Hürriyet was acting as the defender of uncompromising Turkish nationalism in Europe. Hürriyet distributes more than 100,000

\footnotetext{
${ }^{19}$ The suppression of compulsory religious instruction at school and of the DİB, the stopping of State construction of mosques in Alevi villages and more generally of assimilation attempts, the suppression of religious inscription on identity cards ; and an end to the partiality of State media.

${ }^{20}$ See for example M. Demir, "Gizli Alevi toplantısı", Hürriyet, $.23^{\text {rd }}$ June 2000 or B. Miser, "Aleviler'den AB'ye şikâyet", Milliyet, $23^{\text {rd }}$ June 2000.

${ }^{21}$ From the end of November 2000 to February 2001, and again from mid-May to the end of June 2001.
} 
copies daily in Germany and thus clearly dominates the German-Turkish media (Zentrum für Türkei-Studien 1997). Here it must be noted that this campaign, albeit driven from Turkey, was released in the European edition of the daily, which is different from the Turkish one, and was not covered at all in the Turkish public sphere - nor in the German one. This campaign led to the end of the 'historical' unity of Alevists in Europe. For the AABF, cooperating with the FEK was thinkable in Germany for a limited and well-defined aim. But it became unthinkable as soon as it was portrayed as treachery to the Nation.

A last development may well be related to the aforementioned ones. At the beginning of 2002, two proceedings were initiated against the Cultural Association of the Union of Alevi-Bektashi organizations (ABKB), the biggest federation of Alevist organizations both in Turkey and among the migrants. The presence of the words 'alevi', 'cem' and 'cemevi' in its statute was claimed to constitute separatism. Thus, the religious distinctness claimed by the Alevists was criminalized. Finally, the ABKB was closed down in February 2002 by a judiciary decision of Ankara's Security Directorate. In April 2002, another Alevist federation was created, the European Confederation of Alevi Communities (AABK), but it includes only organizations in Europe, and no Turkish ones.

As activists try to transnationalize recognition, there is a parallel 'de-legitimization' and 'criminalization' of Alevism, and of what has been interpreted as its support from abroad, by Turkish institutions and nationalist actors. Are all these episodes related? It would be difficult to find a definite answer to this question. However, it is certain that up until now, Alevists have not been able to export the recognition they obtained in Berlin and from the European Commission to other political spaces, and notably to Turkey.

\section{Conclusion}

Within Alevist discourses, Aleviness is presented as an unity undivided by state boundaries. Alevist politics of identity among the migrants is clearly inscribed into a transnational political field, and always related to developments in Turkey.

The relatively independent trajectories of one and the same movement in different political spaces show how much institutions define the pertinent categories and regulate the access to recognition and resources. Alevist claims are situated differently, institutionally and discursively, in local, national and supranational spaces. Political opportunity structures,

${ }^{22}$ C. Oğuzer "Bu böyle gitmez, gitmemelidir !", Hürriyet, European edition, $25^{\text {th }}$ January 2001. 
institutional frameworks, as well as contextual balances of power strongly influence the possibilities of action, and thus ways in which activists frame their claims. Therefore, these contexts lead to divergent strategies by the movements. Moreover, the very recognition of the organization in Berlin implied its adaptation to the environment in terms of framing and legal requirements, and thus its disjunction from the movement at home and elsewhere.

But these different state practices, legal frames and supranational institutions are related and intertwined in situating Aleviness. Thus, it is a multilevel and entangled process. Some actors - activists, but also state institutions - try to generalize, nationalize or even transnationalize claims and recognitions; but they come up against the obstacle of different existing conditions elsewhere, and against other actors - here again state institutions, media as well as activists - attempting to limit these generalizing efforts. In this particular case, 'restricting' attempts have until now had the upper hand.

Why is this the case? Is the Alevist movement in Germany, which is not sponsored from Turkey and therefore quite autonomous, more adaptable to new contexts than other, more structured movements? Does the extremely divided and fluid character of the Alevist movement explain why in every context, a different branch attempts to take advantage of the existing opportunities? Divergent trajectories of Alevism indicate that the continuity between mobilizations at home and abroad - and thus the 'transnational' dimension - is often overestimated, by abstracting movements from their concrete contexts and the constraints they involve. The theoretical challenge remains to analyze these multilevel processes, complex actors and entangled spaces.

\section{REFERENCES}

AABF. 2002. Lehrplanentwurf für den alevitischen Religionsunterricht. Cologne.

Amiraux, Valérie. 2001. Acteurs de l'islam entre Allemagne et Turquie, Parcours militants et expériences religieuses. Paris : L'Harmattan.

Baumann, Gerd. 1998. "Body politics or bodies of culture ?", Cultural Dynamics 10(3), pp. 263-280.

Benford, Robert D. 1987. Framing Activity, Meaning, and Social Movement Participation : The Nuclear Disarmament Movement. Austin : University of Texas, $\mathrm{PhD}$ thesis.

Benford, Robert D., Snow, David A. 2000. "Framing processes and social movements : an overview and assessment", Annual Review of Sociology, 26, pp. 611-639.

Bozarslan, Hamit. 1994. "Au-delà de l'abolition du Khalifat. Laïcité, Etat-Nation et contestation kurde", Les annales de l'autre islam, 2, pp. 225-235. 
Çağlar, Ayşe. 1998. "Popular Culture, marginality and institutional incorporation. GermanTurkish Rap and Turkish Pop in Berlin", Cultural Dynamics, 10(3), pp. 243-261.

Coşkun, Zeki. 1995. Aleviler, Sünniler ve ... öteki Sivas. Istanbul : Iletişim.

Erman, Tahire and Göker, Emrah. 2000. "Alevi politics in Contemporary Turkey", Middle Eastern Studies, 36(4) October, pp. 99-118.

European Commission. 2000. 2000 Regular Report from the Commission on the Progress Turkey's Progress towards Accession, Brussels.

FUAF. 2000. Les objectifs de la fédération des unions des alévis en France. Paris.

Gamson, William and Meyer, David S. 1996. "The Framing of Political Opportunity". in McAdam, Doug, McCarthy, John D., Zald, Mayer N. (eds.), Comparative Perspectives on Social Movements : Political Opportunities, Mobilizing Structures, and Cultural Framings. Cambridge : Cambridge University Press, pp. 275-290.

Goffman, Erving. 1974. Frame Analysis : An Essay on the Organization of Experience. New York : Harper Colophon.

Hall, Stuart. 1982. "The rediscovery of ideology : return to the repressed in media studies". In Gurevitch, M., Benett T., Curon J., Woolacott J., Culture, Society and the Media. New York : Methuen, pp. 56-90.

Heitmeyer Wilhelm (ed.). 1997. Verlockender Fundamentalismus : türkische Jugendliche in Deutschland, Frankfurt am Main : Suhrkamp.

Kaya, Ayhan. 1998. "Multicultural Clientelism and Alevi Resurgence in the Turkish Diaspora: Berlin Alevis", New perspectives on Turkey, 18 Spring, pp. 23-49.

Kehl-Bodrogi, Krisztina. 2001. "Alevis in Germany on the Way to Public Recognition?", ISIM Newsletter, 8, p. 9.

Kitschelt, Herbert P. 1986. "Political Opportunity Structures and Political Protest: AntiNuclear Movements in Four Democracies", British Journal of Political Science, 16, pp. 57-85.

Koopmans, Ruud, Statham, Paul. 2000. "Challenging the liberal Nation-State ?

Postnationalism, Multiculturalism, and the Collective Claims-Making of Migrants and Ethnic Minorities in Britain and Germany", in Koopmans, Ruud, Statham, Paul (eds.), Challenging Immigration and Ethnic Relations Politics, Comparative European Perspective. Oxford : Oxford University Press, p. 189-232.

Mandel, Ruth. 1990. "Shifting centres and emergent identities: Turkey and Germany in the lives of Turkish Gastarbeiter", in Eickelman, Dale, Piscatori James (eds.) Muslim travellers. Pilgrimage, migration, and the religious imagination. London: Routledge, pp. 153-171.

Massicard, Elise. 2002. Construction identitaire, mobilisation et territorialité politique. Le mouvement aléviste en Turquie et en Allemagne depuis la fin des années 1980. Unpublished PhD thesis, Institut d'Etudes Politiques de Paris.

Massicard, Elise. 2003. "Alevism as a productive misunderstanding: the Hacıbektaş festival", in Jongerden, Joost, White, Paul (eds.), Turkey's Alevi enigma : A comprehensive overview. Leiden : Brill, pp. 125-140.

Oberverwaltungsgericht Berlin. 1998. Urteil OVG7B 4.98/VG 3A 2196.93, Berlin. 
Özdil, A.-Ö. 1999. Aktuelle Debatten zum Islamunterricht in Deutschland. Hambourg: E.B.Verlag.

Ryan, C. 1991. Prime Time Activism. Boston : South End Press.

Schüler, Harald. 1998. Die türkischen Parteien und ihre Mitglieder. Hambourg : Deutsches Orient-Institut.

Sökefeld, Martin. 2000. "Religion or Culture ? Concepts of Identity in the Alevi Diaspora", unpublished manuscript.

Sökefeld, Martin. 2001. "Contesting the Nation in Diaspora : Alevis in Germany and a Media Discourse", unpublished manuscript.

Sökefeld, Martin. 2002. "Alevi Dedes in the German diaspora : The transformation of a religious institution", Zeitschrift für Ethnologie 127, pp. 163-186.

Väth, Gerhard. 1993. "Zur Diskussion über das Alevitum", Zeitschrift für Türkei-Studien 6(2), pp. 211-222.

Vertovec, Steve. 1996. "Berlin Multikulti: Germany, 'foreigners' and 'world-openness', New Community 22(3), July, pp. 381-399.

Vorhoff, Karin. 1995. Zwischen Glaube, Nation und neuer Gemeinschaft : alevitische Identität in der Türkei der Gegenwart. Berlin : Klaus Schwarz.

Zentrum für Türkeistudien. 1997. Medienkonsum der türkischen Bevölkerung in Deutschkand und Deutschlandbild im türkischen Fernsehen. Essen : Zentrum für Türkeistudien. 